\title{
Elective egg freezing: what is the vision of women around the globe?
}

\author{
Susan Nasab*,1(D), Lindsey Ulin ${ }^{1}$, Chikara Nkele1, Jaimin Shah'1, Mazen E Abdallah ${ }^{1,2}$ \& \\ Baha M Sibai ${ }^{1}$ \\ ${ }^{1}$ Department of Obstetrics \& Gynecology, McGovern Medical School, The University of Texas Health Science Center at Houston, \\ Houston, TX 77030, USA \\ ${ }^{2}$ Houston Fertility Institute (HFI), TX 77030, USA \\ *Author for correspondence: Tel.: +713 500 6412; susan.hosseininasab@uth.tmc.edu
}

\begin{abstract}
Aim: The interest in oocyte cryopreservation (OC) for nonmedically indicated reasons is increasing. Knowing women's beliefs and knowledge from various geographic regions could help providers to understand the similarities and differences that could facilitate proper counseling. Materials \& methods: Articles about social egg freezing published over the past 18 years were extracted from the literature. Results: We demonstrated that there are common rationales toward OC among women in the USA and other countries. The ultimate goal was to prolong fertility. The most commonly reported reasons were aging, lack of partner, career and financial status. Conclusion: The beliefs and rationales toward elective OC among women in the USA and other countries are consistent.
\end{abstract}

Lay abstract: The interest in oocyte cryopreservation for nonmedical reasons, known as elective egg freezing, is increasing, owing to several personal and social factors. The understanding of the attitudes and beliefs of women from a variety of geographies could aid in the provision of proper counseling. This review examined prior literature and demonstrated that there are common rationales for oocyte cryopreservation, including aging, lack of partner, career, financial status and not being ready to have a child. It highlighted that there is a necessity for further education and awareness.

First draft submitted: 8 June 2019; Accepted for publication: 15 August 2019; Published online: 31 March 2020

Keywords: elective egg freezing $\bullet$ fertility preservation $\bullet$ oocyte cryopreservation $\bullet$ social egg freezing

In the USA, the birth rate for women 40-44 years of age has risen over the last three decades. The 2015's rate for this age group is the highest since 1966 (11 births per 1000 women) [1]. Based on birth data released by CDC, birth rates have declined for women in their 20s, but increased for women in their 30s and early 40s [1].

This trend, which is not only identified in the USA, has been affecting childbearing decisions among women across the globe. Multiple nonmedical or social reasons have influenced family planning among reproductive aged women [2].

Elective egg freezing, also called social egg freezing, is defined as oocyte cryopreservation (OC) for potential future use by women who are choosing to delay childbearing for personal reasons, such as career pursuits, advancement in education, lack of a partner or financial stability. The first successful human OC and fertilization was reported in 1986 by C Chen, during which he achieved a successful twin pregnancy [3]. Cryopreservation for medical reasons, such as cancer, is already considered as an established method, but it is a fairly new concept for social reasons [4-7]. In 2008, the American Society of Reproductive Medicine announced OC as experimental and suggested that more research and investigations are needed over a longer period [8]. Since then multiple investigators have studied OC in more depth and numerous papers have been published. In 2010, Cobo et al. conducted a randomized controlled trial which examined pregnancy rates of 600 young women who received either fresh or vitrified donor oocytes, and interestingly found no difference in pregnancy rates [9]. Finally, in 2013, the American Society of Reproductive Medicine announced that elective oocyte preservation is no longer considered experimental [10]. However, due to 
limited data on emotional affects, safety, efficacy, ethics and cost-effectiveness, they did not recommend elective OC, but continued to support cryopreservation for medical reasons, such as cancer treatment.

Prior studies have reported personal and social reasons for pursuing elective egg freezing [11-18]. In the USA, the most common indications for elective OC include aging, lack of a partner and financial constraints $[2,19]$.

However, moving from medical OC to social egg freezing, reflections concerning the social debate raised by this practice focused on marketing, interpretation of the impact and meaning of such technology and needs to be addressed. Can social egg freezing lead to improvement in a woman's quality of life and a decrease in fertility anxieties? This important question has been discussed in previous literature and by different societies [20]. The USA is considered a country with residents from all over the world, with a diverse culture and background. Knowing women's attitudes, beliefs and knowledge from a variety of geographic regions can help providers to understand the similarities and differences, which could facilitate proper approach and counseling. Hence, we were interested in identifying the beliefs and attitudes toward social egg freezing around the world.

\section{Materials \& methods}

Inclusion criteria

Primary articles that studied women interested in elective egg freezing were initially selected. Only studies designed as a survey or interview and published during 2000-2018 were included. The outcomes were to evaluate attitudes and beliefs toward elective egg freezing. In general, the responders who believed OC to be a potential fertility preservation option were reported as 'Supporters' and the responders who were in disagreement the option were considered as 'Nonsupporters'. Only articles written in English were included.

\section{Review of literature \& study selection}

Pubmed, Medline and Cochrane were searched. The following medical subject headings, major topics or terms were used for the literature search: elective egg freezing, social egg freezing, oocyte cryopreservation and nonmedically indicated egg freezing. Two independent reviewers reviewed all primary selected articles. Full manuscripts of the relevant articles were reviewed carefully, and all nonrelevant papers, which were selected by electronic search, were excluded. The studies, which were designed as a survey or interview, were included in the study.

Demographic characteristics of the survey responders such as age, relationship status, educational level, as well as their positive/supportive versus negative/nonsupportive beliefs toward social egg freezing were reported. The studies are ordered chronologically in Table 1, based on the period of when the study was performed, not based on the year of publication $[2,11-17,19,21-34]$.

\section{Results}

A total of 1135 citations were retrieved electronically based on the search strategy, of which 1078 were excluded through review of title or abstract. Full manuscripts of 57 published articles about OC for nonmedically indicated reasons were reviewed in detail. Subsequently 22 original studies, which were designed as a survey or interview, were included in our review. Out of those 22 studies, 13 (59\%) were designed as online surveys, and the rest were designed as postal or paper questionnaires, telephonic surveys or in-person interview. A total of 17 (77\%) studies included females only. Moreover, 10 out of 22 were performed in European countries, 7 in the USA, 2 in Canada, 2 in the Middle East and 2 in East Asia (the different characteristic and findings of reviewed studies are summarized in Table 1).

\section{Positive rationales}

We commonly found that the rationales for electing to cryopreserve oocytes centered on goals that women wanted to accomplish prior to having children. Some of the goals included accomplishments such as finding a partner, achieving more financial stability and career-related goals.

In general, there was significant support toward elective egg freezing by American and Non-American populations, mainly by single or childless women, or women with more financial and career stability. Some of the common trends seen among women in Belgium, Denmark, Sweden, USA and UK in support of elective cryopreservation, included allowing more time for financial stability, more time to find a partner and success rates of procedures (Table 1). Women in the Netherlands who were considering oocyte banking stated that their wish to share parenthood with a future partner overruled their concern for possible complications from banking [14]. In a cross-sectional study of female medical students in Singapore, $46.5 \%$ of them cited finding a partner as a reason for OC [26]. A total of 66\% 
Table 1. Study characteristics.

\begin{tabular}{|c|c|c|c|c|c|c|c|c|c|}
\hline Study (year) ${ }^{\dagger}$ & Country & $\begin{array}{l}\text { Type of } \\
\text { survey }\end{array}$ & $\begin{array}{l}\text { Numbers } \\
(\mathrm{F} / \mathrm{M})^{\ddagger}\end{array}$ & $\begin{array}{l}\text { Age } \\
\text { range } \\
\text { (mean) }\end{array}$ & Population & $\begin{array}{l}\text { Educational } \\
\text { level }\end{array}$ & Marital status & Beliefs & Ref. \\
\hline $\begin{array}{l}\text { Lampic et al. } \\
\text { (2004) }\end{array}$ & Sweden & Postal & $\begin{array}{l}401 \\
(222 / 179)\end{array}$ & (24) & $\begin{array}{l}\text { Uppsala University } \\
\text { students }\end{array}$ & Undergraduate & $\begin{array}{l}50 \% \text { in } \\
\text { relationship }\end{array}$ & $\mathrm{N} / \mathrm{A}$ & [30] \\
\hline $\begin{array}{l}\text { Vallejo et al. } \\
(2005-2006)\end{array}$ & USA & Chart review & 20 & (38.6) & $\begin{array}{l}\text { Women who } \\
\text { underwent elective } \\
\text { OC cycle at } \\
\text { Reproductive } \\
\text { Medicine } \\
\text { Associations of New } \\
\text { York }\end{array}$ & $\begin{array}{l}100 \% \text { bachelor, } \\
75 \% \text { masters or } \\
\text { professional } \\
\text { degree }\end{array}$ & Single & - Prolong fertility & [19] \\
\hline $\begin{array}{l}\text { Hodes-Wertz } \\
\text { et al. } \\
(2005-2011)\end{array}$ & USA & $\begin{array}{l}\text { Online and } \\
\text { postal }\end{array}$ & 183 & (38) & $\begin{array}{l}\text { Women who } \\
\text { underwent OC at } \\
\text { fertility center at } \\
\text { New York Langone } \\
\text { Medical Center }\end{array}$ & $\mathrm{N} / \mathrm{A}$ & Never married & $\begin{array}{l}\text { Reasons for not pursuing } \\
\text { childbearing earlier: } \\
\text { - Aging } \\
\text { - Lack of partner } \\
\text { - Professional/financial reasons } \\
\text { - Too large of commitment }\end{array}$ & [20] \\
\hline $\begin{array}{l}\text { Gorthi et al. } \\
\text { (2009) }\end{array}$ & UK & $\begin{array}{l}\text { Paper ques- } \\
\text { tionnaire }\end{array}$ & 200 & $18-30$ & $\begin{array}{l}\text { Medical students vs } \\
\text { nonmedical students } \\
\text { at Leeds University }\end{array}$ & University & $\begin{array}{l}63 \% \text { medical } \\
\text { students single, } \\
25.8 \% \\
\text { nonmedical } \\
\text { students single }\end{array}$ & $\begin{array}{l}\text { Reasons to postpone family: } \\
\text { - Career } \\
\text { - Financial stability } \\
\text { - Marriage }\end{array}$ & [31] \\
\hline $\begin{array}{l}\text { Liu et } \\
\text { al. (2010) }\end{array}$ & Canada & Online & 20 & $30-42$ & $\begin{array}{l}\text { Medical directors of } \\
\text { Canadian ART Clinics }\end{array}$ & $\mathrm{N} / \mathrm{A}$ & $\mathrm{N} / \mathrm{A}$ & - Prolong fertility & [15] \\
\hline $\begin{array}{l}\text { Stoop at } \\
\text { al. (2010) }\end{array}$ & Belgium & Online & 1024 & $\begin{array}{l}21-40 \\
(28.5)\end{array}$ & $\begin{array}{l}\text { Women in national } \\
\text { database }\end{array}$ & Medium-high & $\begin{array}{l}\text { Married or } \\
\text { cohabitating }\end{array}$ & $\begin{array}{l}\text { - No effect on future fertility } \\
\text { - Health and safety of children } \\
\text { - More financial } \\
\text { reimbursement } \\
\text { - More guarantee for success } \\
\text { - Treatment less complex } \\
\text { - If no children yet }\end{array}$ & [13] \\
\hline $\begin{array}{l}\text { Bavan } \\
\text { et al. (2011) }\end{array}$ & USA & Online & 328 & $\begin{array}{l}17-31 \\
(22)\end{array}$ & $\begin{array}{l}\text { Female students in } \\
\text { various universities in } \\
\text { California }\end{array}$ & University & $\begin{array}{l}51 \% \text { in } \\
\text { relationship }\end{array}$ & $\mathrm{N} / \mathrm{A}$ & [32] \\
\hline $\begin{array}{l}\text { Brezis } \\
\text { et al. (2011) }\end{array}$ & Israel & $\begin{array}{l}\text { Online, } \\
\text { interview, } \\
\text { telephone }\end{array}$ & 840 & & $\begin{array}{l}\text { - ART unit directors } \\
\text { - Bioethics experts } \\
\text { - Medical students } \\
\text { - Members of } \\
\text { general population }\end{array}$ & Graduate & $\mathrm{N} / \mathrm{A}$ & $\mathrm{N} / \mathrm{A}$ & [33] \\
\hline $\begin{array}{l}\text { Lallemant } \\
\text { et al. (2012) }\end{array}$ & $\begin{array}{l}\text { UK and } \\
\text { Denmark }\end{array}$ & Online & 973 & $\begin{array}{l}18-68 \\
(31)\end{array}$ & General population & $\begin{array}{l}50 \% \text { above high } \\
\text { school }\end{array}$ & $\begin{array}{l}81 \% \text { in } \\
\text { relationship }\end{array}$ & $\begin{array}{l}\text { 1. Positive rationales: } \\
\text { - Young age } \\
\text { - Single status } \\
\text { - Previous divorce } \\
\text { - No children yet } \\
\text { - Difficulty conceiving } \\
\text { - Part-time job } \\
\text { - Medical indication (cancer) } \\
\text { 2. Negative rationales } \\
\text { - Career reasons } \\
\text { - To allow time to find right } \\
\text { partner } \\
\text { - Financial reasons }\end{array}$ & [9] \\
\hline $\begin{array}{l}\text { De Groot } \\
\text { et al. (2012) }\end{array}$ & $\begin{array}{l}\text { The } \\
\text { Nether- } \\
\text { lands }\end{array}$ & $\begin{array}{l}\text { In-person } \\
\text { interview }\end{array}$ & 20 & (36) & $\begin{array}{l}\text { Women on waiting } \\
\text { list for oocyte } \\
\text { banking at a Dutch } \\
\text { University medical } \\
\text { center }\end{array}$ & $\begin{array}{l}\text { University }> \\
\text { college }>\text { sec- } \\
\text { ondary } \\
\text { vocational } \\
\text { education }\end{array}$ & Single & $\begin{array}{l}\text { 1. Positive rationales } \\
\text { - To prolong fertility, } \\
\text { - Resulting children are healthy } \\
\text { - Time to find partner } \\
\text { 2. Negative rationales } \\
\text { - Pain of follicle aspiration } \\
\text { - Hormonal medication }\end{array}$ & [12] \\
\hline $\begin{array}{l}\text { Tan } \\
\text { et al. (2012) }\end{array}$ & Singapore & Online & 129 & $20-31$ & $\begin{array}{l}\text { Female medical } \\
\text { students }\end{array}$ & Graduate & $\mathrm{N} / \mathrm{A}$ & $\begin{array}{l}\text { - Consider OC if government } \\
\text { subsidy } \\
\text { - Career reasons } \\
\text { - Current lack of partner, } \\
\text { - Age }>30\end{array}$ & [24] \\
\hline
\end{tabular}




\section{Table 1. Study characteristics (cont.).}

\begin{tabular}{|c|c|c|c|c|c|c|c|c|c|}
\hline Study (year) ${ }^{\dagger}$ & Country & $\begin{array}{l}\text { Type of } \\
\text { survey }\end{array}$ & $\begin{array}{l}\text { Numbers } \\
(\mathrm{F} / \mathrm{M})^{\ddagger}\end{array}$ & $\begin{array}{l}\text { Age } \\
\text { range } \\
\text { (mean) }\end{array}$ & Population & $\begin{array}{l}\text { Educational } \\
\text { level }\end{array}$ & Marital status & Beliefs & Ref. \\
\hline $\begin{array}{l}\text { Wennberg } \\
\text { et al. } \\
\text { (2013) }\end{array}$ & Sweden & Postal & $\begin{array}{l}1661, \\
(987,674)\end{array}$ & $30-39$ & $\begin{array}{l}\text { General population: } \\
\text { - Stockholm (urban } \\
\text { cohort) } \\
\text { - Any part of Sweden } \\
\text { (national cohort) }\end{array}$ & $\begin{array}{l}\text { University }> \\
\text { college }>\text { basic } \\
\text { school }\end{array}$ & $\begin{array}{l}\text { Married or } \\
\text { cohabitating }\end{array}$ & $\begin{array}{l}\text { 1. Positive rationales } \\
\text { - Medical reasons }(94 \%) \\
\text { - Urban cohort more positive } \\
\text { than national cohort } \\
\text { - Social reasons }(70 \%) \\
\text { - Single status }\end{array}$ & {$[10]$} \\
\hline $\begin{array}{l}\text { Yu et al. } \\
\text { (2014) }\end{array}$ & USA & Online & $\begin{array}{l}239(216, \\
23)\end{array}$ & $26-30$ & $\begin{array}{l}\text { Ob/GYN resident } \\
\text { physicians }\end{array}$ & MD & $\mathrm{N} / \mathrm{S}$ & $\begin{array}{l}\text { 1. Positive rationales } \\
\text { - Cancer diagnosis } \\
\text { - Inform patients } \\
\text { 2. Negative rationales } \\
\text { - Career reasons } \\
\text { - Young age } \\
\text { - Not pressure patients into } \\
\text { childbearing }\end{array}$ & [34] \\
\hline $\begin{array}{l}\text { Ter Keurst } \\
\text { et al. (2014) }\end{array}$ & UK & Online & 257 & $\begin{array}{l}28-35 \\
(31)\end{array}$ & $\begin{array}{l}\text { Childless women who } \\
\text { wished to have } \\
\text { children }\end{array}$ & University & In relationship & $\begin{array}{l}\text { - Achieve parenthood } \\
\text { - Having children at a later age } \\
\text { - Fewer ethical concerns }\end{array}$ & [35] \\
\hline $\begin{array}{l}\text { Stoop } \\
\text { et al. (2014) }\end{array}$ & Belgium & Telephone & 138 & (43) & $\begin{array}{l}\text { Women seen at clinic } \\
\text { for banking }\end{array}$ & $\mathrm{N} / \mathrm{A}$ & $\begin{array}{l}50 \% \text { in } \\
\text { relationship }\end{array}$ & $\begin{array}{l}\text { - Insurance against future } \\
\text { infertility } \\
\text { - More time to find partner } \\
\text { - Prevent regret }\end{array}$ & [27] \\
\hline $\begin{array}{l}\text { Daniluk } \\
\text { et al. (2015) }\end{array}$ & Canada & Online & 500 & $18-38$ & $\begin{array}{l}\text { Childless, presumed } \\
\text { fertile women }\end{array}$ & $\begin{array}{l}\text { College or } \\
\text { university }>\text { high } \\
\text { school }>\text { post- } \\
\text { grad }\end{array}$ & $\begin{array}{l}\text { No part- } \\
\text { ner }>\text { married/ } \\
\text { cohabitating }\end{array}$ & $\begin{array}{l}\text { - Medical reasons (Cancer) } \\
\text { - No partner } \\
\text { - Self or partner not ready to } \\
\text { have children }\end{array}$ & [11] \\
\hline $\begin{array}{l}\text { Lewis } \\
\text { et al. (2015) }\end{array}$ & USA & Online & $\begin{array}{l}1064 \\
(590,474)\end{array}$ & $18-65$ & General population & $\begin{array}{l}\text { Bachelor de- } \\
\text { gree }>\text { graduate } \\
\text { degree }>\text { some } \\
\text { college }\end{array}$ & $\begin{array}{l}\text { Married > never } \\
\text { married }\end{array}$ & $\begin{array}{l}\text { 1. Positive rationales } \\
\text { - Cancer diagnosis } \\
\text { - Career plans } \\
\text { - Current lack of partner } \\
\text { - Insufficient funds for child } \\
\text { rearing } \\
\text { - Higher income } \\
\text { - Atheism or agnosticism } \\
\text { - No children yet } \\
\text { 2. Negative rationales } \\
\text { - Unethical } \\
\text { - Creation of older parents } \\
\text { unable to care for their children } \\
\text { - Older age }\end{array}$ & [18] \\
\hline $\begin{array}{l}\text { Baldwin } \\
\text { et al. (2015) }\end{array}$ & UK & Online/refer & 23 & $\begin{array}{l}36-39 \\
(36.7)\end{array}$ & $\begin{array}{l}\text { Women who } \\
\text { underwent elective } \\
\text { OC }\end{array}$ & $\begin{array}{l}\text { University, } 65 \% \\
\text { postgraduate or } \\
\text { professional } \\
\text { qualifications }\end{array}$ & $\begin{array}{l}87 \% \text { not in } \\
\text { relationship }\end{array}$ & - Prolong fertility & \\
\hline $\begin{array}{l}\text { Kilic } \\
\text { et al. (2016) }\end{array}$ & Turkey & Interview & 21 & $\begin{array}{l}\text { Median } \\
\text { age } 40\end{array}$ & $\begin{array}{l}\text { Women who } \\
\text { underwent/in the } \\
\text { process of elective OC }\end{array}$ & $\begin{array}{l}\text { University } \\
\text { degrees in all } \\
\text { except one who } \\
\text { was high school } \\
\text { graduate) }\end{array}$ & All unmarried & $\begin{array}{l}\text { - Positive influence on the } \\
\text { future relationship } \\
\text { - Preserve fertility } \\
\text { - Boost self-esteem and self } \\
\text { worth } \\
\text { - Concern to be rejected by } \\
\text { men due to lost fertility }\end{array}$ & \\
\hline $\begin{array}{l}\text { Kim } \\
\text { et al. (2016- } \\
17)\end{array}$ & $\begin{array}{l}\text { South } \\
\text { Korea }\end{array}$ & $\begin{array}{l}\text { Paper ques- } \\
\text { tionnaire }\end{array}$ & 91 & (37.1) & $\begin{array}{l}\text { Women who } \\
\text { underwent elective } \\
\text { OC }\end{array}$ & Not reported & $85 \%$ Single & $\begin{array}{l}\text { - Lack of partner } \\
\text { - Professional reasons } \\
\text { - Insurance against future } \\
\text { fertility }\end{array}$ & \\
\hline $\begin{array}{l}\text { Inhorn } \\
\text { et al. (2014- } \\
\text { 16) }\end{array}$ & $\begin{array}{l}\text { USA } \\
\text { Israel }\end{array}$ & Interview & 114 & $\begin{array}{l}25->40 \\
(36)\end{array}$ & $\begin{array}{l}\text { Women who } \\
\text { underwent elective } \\
\text { OC }\end{array}$ & $\begin{array}{l}72 \% \text { graduate } \\
\text { degree }\end{array}$ & $78 \%$ Single & $\begin{array}{l}\text { - Women have higher } \\
\text { expectations } \\
\text { - Career } \\
\text { - Lack of right partner }\end{array}$ & \\
\hline $\begin{array}{l}\text { Esfandiari } \\
\text { et al. (2018) }\end{array}$ & USA & Online & $\begin{array}{l}113 \\
(103 / 10)\end{array}$ & $26->35$ & $\begin{array}{l}\text { Ob/GYN residents } \\
\text { and fellows }\end{array}$ & $\begin{array}{l}100 \% \text { graduate } \\
\text { degree }\end{array}$ & $\begin{array}{l}58 \% \text { married, } \\
23 \% \text { single }\end{array}$ & - Lack of partner & \\
\hline
\end{tabular}


of respondents from an electronic survey in Canada supported cryopreservation for young women [13]. From this same group of supporters the top four factors that influenced their decision were financial costs $(85.6 \%)$, health risks to themselves $(86.4 \%)$ or their offspring $(87.8 \%)$ and success rates $(82 \%)$ [13]. In a cross-sectional study of 1064 women in the USA, it was found that people supported elective OC based on the following criteria: delayed childbearing for career advancement (72\%), current lack of a partner (63\%) and insufficient funds for child rearing (58\%) [2].

\section{Negative rationales}

Although throughout the studies there was a lot of support for OC, there were some individuals who expressed dissent. Some of the rationales for their dissent were lack of evidence about effect on future fertility, finding OC unethical, complexity of treatment and creation of older parents who may not be able to care for their children. One study in the USA reported that an older age of 45-65 years was associated with lower support for OC [2]. In a study of women at a Dutch medical center on a waiting list for OC, they expressed their fear of pain from follicle aspiration, and emotional imbalance from hormones as reasons for being hesitant to move forward with the procedure [14].

\section{Discussion}

Based on our review, overall women's rationales toward OC in the USA echoed the same feelings of many women across the world in places such as the UK, Denmark, Belgium, Sweden, Singapore and the Netherlands.

This study has several strengths and limitations. A limitation of the study was that all types of surveys were included in the study, including online, telephonic, mail and so on. It would be ideal to have face-to-face interviews, or at least all the surveys designed in the same style. However, per our search, there are not many surveys regarding elective egg freezing around the world, and hence we included all available ones.

What is more, the difference in survey questions and their wording/phrasing (open ended vs straightforward questions) can affect the response of survey takers.

This review is strengthened by its heterogeneity. Original studies were performed in different geographic locations, enrolling different populations and ethnicities, with different personal, religious and ethical beliefs, and this increases the generalizability. Given the fact that the population in the USA is also very diverse, physicians can benefit from this information in terms of understanding their patient population, regardless of their background.

\section{Why is knowing patient beliefs \& attitude important? Proper counseling}

For physicians to select the appropriate patient population, to use reasonable and effective strategies and to counsel about elective egg freezing, it is important to consider the demographics, understandings, beliefs and concerns of the people who are interested. Overall, the most common demographics of people interested in elective OC were single, divorced or widowed, desiring future fertility, childless, having little ethical conflict and having medium to higher incomes. The average age of interested women, or women who had already undergone OC, was around 35. In an oocyte banking center in the Netherlands, the average age of women on their waiting list was 35.8 years [14]. In another center in New York, USA, more than $85 \%$ of women who had undergone cryopreservation were older than 35 years of age [19]. In a study conducted in Canada, which surveyed 16 of the 28 assisted reproductive technology clinics, authors found that all clinics offered cryopreservation as an option to women at 35-36 years, but the consensus varied among clinics for ages younger or older than this. The data show the importance of proper counseling of patients who are OC candidates and at an appropriate age [35], and their education about the success rate at each age group [10,36,37].

\section{Appropriate knowledge \& awareness}

The other important issue is the overall knowledge of women about fertility reserve and fertility preservation options. More importantly, do they have accurate information about fertility preservation success rate and outcomes? Lack of knowledge about female age-related fertility decline has been mentioned in previous studies [38]. In one of the online surveys of childless women in Canada, it found that women averaged $33 \%$ when questioned about infertility and treatment [13]. A survey of 129 Singaporean medical students surveyed via an online questionnaire found that only $36.4 \%$ of them had ever heard of social egg freezing [26]. In another study, $70 \%$ of surveyed women considered $\mathrm{OC}$ as a fertility preservation option, but after receiving more information about the procedure the proportion 
of potential egg freezers decreased to 48.9\% [12]. Of 1914 women surveyed in Belgium between ages 21 and 40, women were more likely to engage in social egg freezing if they were educated and informed about the risk of the procedure, its effect on their future fertility $(75.2 \%)$, and the health of children conceived from preserved oocytes (70.9\%) [29]. In a cross-sectional study of 500 childless women in Canada, only $14.8 \%$ of them rated their knowledge of cryopreservation as 'very' knowledgeable, whereas 53\% of them rated their knowledge as 'some' [39]. When these same participants were asked 12 knowledge questions about cost, risk and viability of oocyte freezing, most women showed a high level of uncertainty with an average of $33 \%$ on the test [39]. $61 \%$ of women believed that physicians should provide information to childbearing women at their annual visits [39]. Moreover, in a recent study in Italy among young female students, $34.3 \%$ have heard about OC for social reasons. They were significantly less aware of age-related decline in fertility and the possibility of using social egg freezing compared with their counterparts in other western countries [40]. Lack of knowledge of fertility is expected to continue to be a problem for those who are choosing to delay child-bearing, unless we educate them on the available preservation options.

Finally, in a recent survey of women who underwent OC, performed by Greenwood et al. [41], those who perceived that they have had adequate counseling reported less regret. $80 \%$ reported that they had adequate information before the process and $69 \%$ perceived adequate emotional support. Those with higher expectation of future success with oocyte preservations had lower odds of regret.

We would like to emphasize the crucial role of physicians to provide informed consent and accurate information, to avoid emotional crises and decrease the rate of regret [36].

\section{Conclusion}

Based on our literature review, elective OC gives an option to certain women to slow down the fertility clock and align it with the time when they find themselves stable enough and sufficiently mentally, emotionally or financially prepared to have a child. Overall, the beliefs and rationales toward elective OC among women in the USA and with other countries appear consistent. Many women in their mid 30s would consider this as an option if they desire to have children in the future, but have not yet accomplished the financial, career or partner goals that they desire. Factors that inhibit women who are interested from actually acting on their interest include lack of finances, ethical dilemmas, complexity of treatment, lack of knowledge about the efficacy, effect on future fertility and viability of oocytes.

In general, knowledge about fertility treatment is low across the globe. As our population of childbearing women continues to age and as cryopreservation techniques and cost continue to improve, we expect there will continue to be a growing demand for elective oocyte services. Offering proper counseling and targeting the appropriate population of women who are interested in cryopreservation would be highly recommended for infertility providers and counselors.

\section{Future perspective}

We speculate that in the next decade elective OC could be considered an option for family planning. Face-to-face survey studies in the future will provide a better picture of the rationales and beliefs toward elective egg freezing. Educational sessions and awareness programs are needed to provide information about available fertility preservation options, which could potentially decrease the rate of regret.

\footnotetext{
Author contributions

S Nasab: study design, study idea, reviewing all the articles in detail and writing the manuscript. Submission and revision. $\mathrm{L}$ Ulin: literature search, writing (introduction part)/editing manuscript. C Nkele: literature search, writing (introduction part)/editing manuscript. J Shah: study design, editing manuscript, revision. ME Abdallah: study idea, reviewing the whole manuscript, mentor. BM Sibai: study design, reviewing and editing the whole manuscript, revision, senior mentor.
}

Financial \& competing interests disclosure

The authors have no relevant affiliations or financial involvement with any organization or entity with a financial interest in or financial conflict with the subject matter or materials discussed in the manuscript. This includes employment, consultancies, honoraria, stock ownership or options, expert testimony, grants or patents received or pending, or royalties.

No writing assistance was utilized in the production of this manuscript. 


\section{Open access}

This work is licensed under the Creative Commons Attribution 4.0 License. To view a copy of this license, visit http://creativecommons.org/licenses/by/4.0/

\section{Executive summary}

- The interest in oocyte cryopreservation for nonmedical reasons, known as elective egg freezing, is increasing, secondary to several personal and social factors.

- Knowing women's attitudes and beliefs coming from other geographic regions could help practitioners to provide proper counseling.

- Among most populations, the most common demographics of people interested in elective oocyte cryopreservation were single, divorced or widowed, desiring future fertility, childless, having little ethical conflict and having medium to higher incomes.

- Rationales for elective egg freezing were mainly centered on goals that women wanted to accomplish prior to having children such as finding a partner, achieving more financial stability and career-related goals.

- Overall, there is a lack of knowledge about female fertility reserve and fertility preservation options around the globe.

- Lack of knowledge about female fertility reserve necessitates further education and awareness.

- Offering proper counseling and targeting the appropriate population of women who are interested in cryopreservation would be highly recommended to the infertility providers and counselors.

\section{References}

Papers of special note have been highlighted as: $\bullet$ of interest

1. National Center for Health Statistics, Centers for disease control and Prevention (2018). www.Cdc.Gov/Nchs/Nvss/Births.Htm

2. Lewis EI, Missmer SA, Farland LV, Ginsburg ES. Public support in the United States for elective oocyte cryopreservation. Fertil. Steril. 106(5), 1183-1189 (2016).

- Shows the attitudes and support toward elective egg freezing in the USA.

3. Chen C. Pregnancy after human oocyte cryopreservation. Lancet 1(8486), 884-886 (1986).

- Important study to cite, as it was the first successful human oocyte cryopreservation and fertilization reported in 1986.

4. Benard J, Calvo J, Comtet M, Benoit A, Sifer C, Grynberg M. [Fertility preservation in women of the childbearing age: indications and strategies]. J. Gynecol. Obstet. Biol. Reprod. (Paris) 45(5), 424-444 (2016).

5. Chaput L, Gremeau AS, Vorilhon S et al. [Fertility preservation in oncology]. Bull. Cancer 105(1), 99-110 (2018).

6. Harada M, Osuga Y. Fertility preservation for female cancer patients. Int. J. Clin. Oncol. 24(1), 28-33 (2019).

7. Rousset-Jablonski C, Chevillon F, Dhedin N, Poirot C. Fertility preservation in adolescents and young adults with cancer. Bull. Cancer 103(12), 1019-1034 (2016).

8. Practice Committee of American Society for Reproductive M, Practice Committee of Society for Assisted Reproductive T. Ovarian tissue and oocyte cryopreservation. Fertil. Steril. 90(Suppl. 5), S241-S246 (2008).

9. Cobo A, Meseguer M, Remohi J, Pellicer A. Use of cryo-banked oocytes in an ovum donation programme: a prospective, randomized, controlled, clinical trial. Hum. Reprod. 25(9), 2239-2246 (2010).

10. Practice Committees of American Society for Reproductive M, Society for Assisted Reproductive T. Mature oocyte cryopreservation: a guideline. Fertil. Steril. 99(1), 37-43 (2013).

- Above two articles are the national guidelines regarding oocyte cryopreservation (the initial and the updated one).

11. Lallemant C, Vassard D, Nyboe Andersen A, Schmidt L, Macklon N. Medical and social egg freezing: internet-based survey of knowledge and attitudes among women in Denmark and the UK. Acta Obstet. Gynecol. Scand. 95(12), 1402-1410 (2016).

12. Wennberg AL, Rodriguez-Wallberg KA, Milsom I, Brannstrom M. Attitudes towards new assisted reproductive technologies in Sweden: a survey in women 30-39 years of age. Acta Obstet. Gynecol. Scand. 95(1), 38-44 (2016).

13. Daniluk JC, Koert E. Childless women's beliefs and knowledge about oocyte freezing for social and medical reasons. Hum. Reprod. 31(10), 2313-2320 (2016).

- Shows attitudes toward egg freezing in women in Canada.

14. De Groot M, Dancet E, Repping $S$ et al. Perceptions of oocyte banking from women intending to circumvent age-related fertility decline. Acta Obstet. Gynecol. Scand. 95(12), 1396-1401 (2016).

15. Stoop D, Nekkebroeck J, Devroey P. A survey on the intentions and attitudes towards oocyte cryopreservation for non-medical reasons among women of reproductive age. Hum. Reprod. 26(3), 655-661 (2011).

- Reports public attitude toward social egg freezing in Belgium. 
16. Baldwin K, Culley L, Hudson N, Mitchell H, Lavery S. Oocyte cryopreservation for social reasons: demographic profile and disposal intentions of UK users. Reprod. Biomed. Online 31(2), 239-245 (2015).

17. Liu KE, Greenblatt EM. Oocyte cryopreservation in Canada: a survey of Canadian ART clinics. J. Obstet. Gynaecol. Can. 34(3), 250-256 (2012).

18. Hammarberg K, Kirkman M, Pritchard N et al. Reproductive experiences of women who cryopreserved oocytes for non-medical reasons. Hum. Reprod. 32(3), 575-581 (2017).

19. Hodes-Wertz B, Druckenmiller S, Smith M, Noyes N. What do reproductive-age women who undergo oocyte cryopreservation think about the process as a means to preserve fertility? Fertil. Steril. 100(5), 1343-1349 (2013).

20. Martinelli L, Busatta L, Galvagni L, Piciocchi C. Social egg freezing: a reproductive chance or smoke and mirrors? Croat. Med. J. 56(4), 387-391 (2015).

21. Lampic C, Svanberg AS, Karlstrom P, Tyden T. Fertility awareness, intentions concerning childbearing, and attitudes towards parenthood among female and male academics. Hum. Reprod. 21(2), 558-564 (2006).

22. Vallejo V, Lee J, Schuman L, et al. Social and psychological assessment of women undergoing elective oocyte cryopreservation: a 7-year analysis. Open J. Obstet. Gynecol. 3, 1-7 (2013).

23. Gorth S, Wright C. EaWYWRTHRI. O-027 Is egg freezing for social reasons a good idea?. Human Reproduction 25, i11-i12 (2010).

24. Bavan B, Porzig E, Baker VL. An assessment of female university students' attitudes toward screening technologies for ovarian reserve. Fertil. Steril. 96(5), 1195-1199 (2011).

25. Brezis M, Malkiel A, Chinitz D, Lehmann LS. Discordant views of experts and laypersons on the adoption of new fertility technology. Med. Care 49(4), 420-423 (2011).

26. Tan SQ, Tan AW, Lau MS, Tan HH, Nadarajah S. Social oocyte freezing: a survey among Singaporean female medical students. J. Obstet. Gynaecol. Res. 40(5), 1345-1352 (2014).

27. Yu L, Peterson B, Inhorn MC, Boehm JK, Patrizio P. Knowledge, attitudes, and intentions toward fertility awareness and oocyte cryopreservation among obstetrics and gynecology resident physicians. Hum. Reprod. 31(2), 403-411 (2016).

28. Ter Keurst A, Boivin J, Gameiro S. Women's intentions to use fertility preservation to prevent age-related fertility decline. Reprod. Biomed. Online 32(1), 121-131 (2016).

29. Stoop D, Maes E, Polyzos NP, Verheyen G, Tournaye H, Nekkebroeck J. Does oocyte banking for anticipated gamete exhaustion influence future relational and reproductive choices? A follow-up of bankers and non-bankers. Hum. Reprod. 30(2), 338-344 (2015).

30. Kilic A, Gocmen I. Fate, morals and rational calculations: freezing eggs for non-medical reasons in Turkey. Soc. Sci. Med. 203, 19-27 (2018).

31. Baldwin K. Conceptualising women's motivations for social egg freezing and experience of reproductive delay. Sociol. Health Illn. 40(5), 859-873 (2018).

32. Esfandiari N, Litzky J, Sayler J, Zagadailov P, George K, Demars L. Egg freezing for fertility preservation and family planning: a nationwide survey of US obstetrics and gynecology residents. Reprod. Biol. Endocrinol. 17(1), 16 (2019).

- A recent survey among obstetric/gynecology resident in the USA, showing their knowledge and attitude toward social egg freezing, important to know as a provider for proper counseling.

33. Inhorn MC, Birenbaum-Carmeli D, Birger $\mathrm{J}$ et al. Elective egg freezing and its underlying socio-demography: a binational analysis with global implications. Reprod. Biol. Endocrinol. 16(1), 70 (2018).

- A recent binational study in the USA and Israel analyzing social attitudes toward egg freezing.

34. Kim R, Yoon TK, Kang IS et al. Decision making processes of women who seek elective oocyte cryopreservation. J. Assist. Reprod. Genet. 35(9), 1623-1630 (2018).

35. Mesen TB, Mersereau JE, Kane JB, Steiner AZ. Optimal timing for elective egg freezing. Fertil. Steril. 103(6), 1551-1556 (2015).

36. Goldman KN. Elective oocyte cryopreservation: an ounce of prevention? Fertil. Steril. 109(6), 1014-1015 (2018).

37. Guzman L, Inoue N, Nunez D et al. What advice should we give our patients to preserve their fertility and avoid needing oocyte donation in the future? - A Social Fertility Preservation program. JBRA Assist. Reprod. 23(2), 106-111 (2019).

38. Mahesan AM, Sadek S, Ramadan H, Bocca S, Paul ABM, Stadtmauer L. Knowledge and attitudes regarding elective oocyte cryopreservation in undergraduate and medical students. Fertil. Res. Pract. 5, 5 (2019).

39. Daniluk JC, Koert E, Cheung A. Childless women's knowledge of fertility and assisted human reproduction: identifying the gaps. Fertil. Steril. 97(2), 420-426 (2012).

40. Tozzo P, Fassina A, Nespeca P, Spigarolo G, Caenazzo L. Understanding social oocyte freezing in Italy: a scoping survey on university female students' awareness and attitudes. Life Sci. Soc. Policy 15(1), 3 (2019).

41. Greenwood EA, Pasch LA, Hastie J, Cedars MI, Huddleston HG. To freeze or not to freeze: decision regret and satisfaction following elective oocyte cryopreservation. Fertil. Steril. 109(6), 1097-1104 e1091 (2018). 